\title{
New insights into the origin and relationships of blastoid echinoderms
}

\author{
Christopher R.C. Paul \\ Acta Palaeontologica Polonica 66 (1), 2021: 41-62 doi:https://doi.org/10.4202/app.00825.2020
}

\begin{abstract}
"Pan-dichoporites" (new informal term) is proposed to unite Cambrian blastozoans, such as Cambrocrinus, Ridersia, and Sanducystis, glyptocystitoid and hemicosmitoid rhombiferans, coronates, blastoids, and Lysocystites. Pan-dichoporite ambulacra have double biserial main axes with brachiole facets shared by pairs of floor (glyptocystitoids), side (blastoid) or trunk (hemicosmitoids, coronates) plates. These axial plates are the first two brachiolar plates modified to form the ambulacral axes. In glyptocystitoids the first brachiole facet in each ambulacrum is shared by an oral and another plate. Hence, these are also two modified brachiolar plates and part of the axial skeleton under the Extraxial Axial Theory (EAT). Pan-dichoporites are also characterized by thecae composed of homologous plate circlets. The unique glyptocystitoid genus Rhombifera bears ambulacral facets on five radial plates, which alternate with five orals. The oral area of Lysocystites (blastoid sensu lato) is very similar, which suggests that rhombiferan radials are homologous with "ambulacrals" of Lysocystites and hence with blastoid lancet plates. This implies derivation of blastoids from glyptocystitoids and suggests that blastoid and coronate radials and deltoids are homologous with rhombiferan infralaterals and laterals. Thus, homologous plate circlets occur in all pan-dichoporites, which strengthens the validity of a pan-dichoporite clade. Under Universal Elemental Homology (UEH), deltoids were homologized with rhombiferan orals, but this is inconsistent with the EAT. Deltoids bear respiratory pore structures and so are perforate extraxial skeletal plates, whereas rhombiferan orals are axial skeleton. The new plate homologies also explain why only five plates form the oral frames of coronates, blastoids and Lysocystites, whereas glyptocystitoids (except Rhombifera) have six oral frame plates; all glyptocystitoids have only five laterals. Hemicosmitoids arose by paedomorphic ambulacral reduction, but the paedomorphosis also affected the thecal plates and stem. Paedomorphosis poses special problems for cladistic character analysis, since the new characters often appear to be plesiomorphic.
\end{abstract}

Key words: Blastozoa, Glyptocystitoida, Hemicosmitoida, Coronata, Blastoidea, homology, phylogeny, ontogeny.

Christopher R.C. Paul [glcrcp@bristol.ac.uk], School of Earth Sciences, University of Bristol, BS8 1RJ, UK. 
This is an open-access article distributed under the terms of the Creative Commons Attribution License (for details please see creativecommons.org), which permits unrestricted use, distribution, and reproduction in any medium, provided the original author and source are credited.

For Full text $(2,183.1 \mathrm{kB})$ 